\title{
Effects of water salinity and organomineral fertilization on leaf composition and production in Passiflora edulis
}

\author{
José T. A. Souza ${ }^{1}$, Járisson C. Nunes ${ }^{2}$, Lourival F. Cavalcante ${ }^{3}$, \\ Juliete A. da S. Nunes ${ }^{4}$, Walter E. Pereira ${ }^{1} \&$ José L. de O. Freire ${ }^{5}$
}

${ }^{1}$ Universidade Federal da Paraíba/Centro de Ciências Agrárias/Programa de Pós-Graduação em Agronomia. Areia, PB. E-mail: thyago.agro@hotmail.com - ORCID: 0000-0002-1508-1136; wep@cca.ufpb.br - ORCID: 0000-0003-1085-0191

${ }^{2}$ Universidade Estadual de Roraima/Programa de Pós-Graduação em Agroecologia/PNPD-Capes. Boa Vista, RR. E-mail: jarisson2006@yahoo.com.br (Corresponding author) - ORCID: 0000-0002-5129-2934

${ }^{3}$ Universidade Federal da Paraíba/Programa de Pós-Graduação em Agronomia/INCT-Sal. Areia, PB. E-mail: lofeca@cca.ufpb.br - ORCID: 0000-0002-8827-4713

${ }^{4}$ Universidade Federal de Santa Maria/Centro de Ciências Rurais/Programa de Pós-Graduação em Agronomia. Santa Maria, RS. E-mail: jullyetearaujo@hotmail.com - ORCID: 0000-0002-8649-7569

${ }^{5}$ Instituto Federal de Educação, Ciência e Tecnologia da Paraíba/Campus Picuí/Coordenação do Curso de Tecnologia em Agroecologia. Picuí, PB. E-mail: prof.lucinio@gmail.com - ORCID: 0000-0002-0671-9185

\section{Key words:}

yellow passion fruit bovine biofertilizer salinity

\begin{abstract}
A B S T R A C T
An experiment was undertaken in Remígio County, Paraíba State, Brazil, from July 2013 to May 2014, in order to evaluate the effects of saline water irrigation, bovine biofertilizer, and potassium type on soil salinity, leaf macronutrient composition, and production of yellow passion fruit cv. BRS Gigante Amarelo. Treatments were distributed in randomized blocks, arranged in a $2 \times 2 \times 2$ factorial design, with reference to electrical conductivity of the water $\left(0.35\right.$ and $\left.4.00 \mathrm{dS} \mathrm{m}^{-1}\right)$, soil with and without bovine biofertilizer, and application of potassium chloride as a conventional treatment $(\mathrm{KCl})$ and in an organic polymer-coated form, supplied monthly. Bovine biofertilizer was diluted in non-saline water (proportion, $50 \%)$ and applied via water at a volume of $6 \mathrm{~L} \mathrm{plant}^{-1}$ one day before transplanting, and then every 90 days. The combination of saline water with bovine biofertilizer raised soil salinity to a similar proportion when comparing saline water and conventional potassium chloride with saline water and polymer-coated potassium chloride. The increase in water saline concentrations associated with both types of potassium chloride and with bovine biofertilizer elevated soil salinity from non-saline to saline. On starting to flower, plants of cv. BRS Gigante Amarelo were deficient in macronutrients other than nitrogen and potassium, but nonetheless produced fruits of an adequate mass for the consumer market.
\end{abstract}

\section{Palavras-chave:} maracujazeiro amarelo biofertilizante bovino salinidade

\section{Água salina e adubação organomineral na composição foliar e produção de Passiflora edulis}

\section{R E S U M O}

Um experimento foi conduzido no município de Remígio, Paraíba, no período de julho/2013 a maio/2014, para avaliar os efeitos da salinidade da água de irrigação, biofertilizante bovino e potássio na salinidade do solo, composição foliar e produção do maracujazeiro amarelo cv BRS Gigante Amarelo. Os tratamentos foram distribuídos em blocos casualizados arranjados

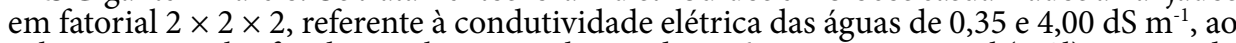
solo sem e com biofertilizante bovino e cloreto de potássio convencional (KCl) e revestido com polímeros orgânicos fornecidos mensalmente. O biofertilizante bovino foi diluído em água não salina na proporção de $50 \%$ e aplicado em volume de $6 \mathrm{~L} \mathrm{planta}^{-1}$ da mistura um dia antes do transplantio e a cada 90 dias. A combinação de água salina com biofertilizante bovino aumentou a salinidade do solo para uma proporção similar entre a água salina e o cloreto de potássio convencional e protegido com polímeros orgânicos. A salinidade da água de irrigação associada a ambos os tipos de cloreto de potássio e biofertilizante elevou o caráter do solo de não salino para salino. As plantas de maracujazeiro BRS Gigante Amarelo, no inicio da floração, exceto em nitrogênio e potássio, estavam deficientes nos demais macronutrientes, mas produziram frutos com massa adequada para o mercado consumidor. 


\section{INTRODUCTION}

Soil or water salinity can have a negative effect on plant nutrition, including yellow passion fruit, a crop that is sensitive to salinity. However, in some parts of the Northeastern semiarid region of Brazil, water with an electrical conductivity above $3 \mathrm{dS} \mathrm{m}^{-1}$ has been used to irrigate crops in the Passifloraceae family (Souza et al., 2016; Lima et al., 2017).

Thus, in these regions crops are produced that are moderately sensitive to moderately tolerant to salts (Dias et al., 2012). Problems caused by salinity are mostly due to a reduced osmotic potential of the soil solution, and the absorption via water of essential nutrients, such as potassium, causing an imbalance in the $\mathrm{K}^{+} / \mathrm{Na}^{+}$ratio, which is responsible for osmotic adjustment in plants (Vieira et al., 2016). As Glaeser et al. (2016) have observed, osmotic adjustment enables water absorption in high salinity conditions, thus contributing to plant growth and production levels.

One of the most common agricultural limitations is the production costs associated with the acquisition and distribution of inputs to crops, such as synthetic mineral fertilizers. One way of reducing these costs is to apply slowrelease mineral fertilizers (Melo Júnior et al., 2015; Chilundo et al., 2016). This practice provides sufficient nutrient availability to plants for a longer period, and lowers lixiviation-related nutrient loss (Bernardes et al., 2015).

Currently, there is global investment in sustainable basic farming practices, with the aim of reducing damage to natural resources. In this context, organic fertilizers are a good option for agricultural crops (Borges et al., 2016; Nascimento et al., 2016). Among the inputs used, bovine biofertilizer is of particular importance for many different crops (Dias et al., 2013). This study therefore aimed to evaluate the effects of irrigation with non-saline and saline water, and the application of bovine biofertilizer and conventional and slow-release potassium on soil salinity, nutritional status, and production of the passion fruit cv. BRS Gigante Amarelo.

\section{Material AND Methods}

The experiment was conducted from July 2013 to May 2014, in the municipality of Remígio, Paraíba State, Brazil $\left(7^{\circ} 00^{\prime}\right.$ $1.95^{\prime \prime} \mathrm{S}, 35^{\circ} 47^{\prime} 55^{\prime \prime} \mathrm{W}$, and $562 \mathrm{~m}$ altitude). The municipality is in the Occidental Curimataú micro-region, a semiarid area of Northeast Brazil. According to the Köppen classification (Alvares et al., 2014), the climate is of the As type (denoting hot and humid), with a rainy period from March to July. Monthly data from 2013 and 2014 for precipitation, air temperature and relative air humidity are presented in Table 1; values relevant to the experimental period (July 2013 to May 2014) were 642 $\mathrm{mm}, 26.5^{\circ} \mathrm{C}$ and $72.3 \%$, respectively. According to the criteria set out by the Brazilian System of Soil Classification (SiBCS) (EMBRAPA, 2013), the soil was a non-saline Dystrophic Regolitic Neosoil.

The chemical and physical characteristics of soil in the $0-40 \mathrm{~cm}$ layer and bovine manure, as fertilizer, are shown in Table 2 (Donagema et al., 2011). The soil's eutrophic aspect, with a base saturation value of $68.59 \%$, is due to crop fertilization by single superphosphate, potassium chloride, and organic
Table 1. Monthly precipitation (P), monthly mean air temperature $(\mathrm{T})$, and monthly mean relative air humidity $(\mathrm{RH})$ during the experimental period

\begin{tabular}{|c|c|c|c|c|c|c|}
\hline \multirow{3}{*}{ Month } & \multicolumn{6}{|c|}{ Year } \\
\hline & \multicolumn{3}{|c|}{2013} & \multicolumn{3}{|c|}{2014} \\
\hline & $\underset{\mathrm{mm}}{\mathbf{P}}$ & $\begin{array}{c}\mathbf{T} \\
{ }^{\circ} \mathbf{C}\end{array}$ & $\begin{array}{c}\text { RH } \\
\%\end{array}$ & $\underset{\mathrm{mm}}{\mathbf{P}}$ & $\begin{array}{c}\mathbf{T} \\
{ }^{\circ} \mathrm{C}\end{array}$ & $\begin{array}{c}\text { RH } \\
\%\end{array}$ \\
\hline January & 38 & 26.7 & 59 & 35 & 28.3 & 72 \\
\hline February & 66 & 24.9 & 45 & 117 & 27.4 & 75 \\
\hline March & 41 & 24.9 & 68 & 53 & 28.2 & 76 \\
\hline April & 135 & 24.7 & 70 & 30 & 28.1 & 74 \\
\hline May & 58 & 24.2 & 76 & 100 & 26.4 & 78 \\
\hline June & 155 & 22.4 & 80 & 110 & 25.2 & 81 \\
\hline July & 118 & 22.0 & 82 & 155 & 25.0 & 81 \\
\hline August & 82 & 21.5 & 86 & 37 & 24.3 & 78 \\
\hline September & 30 & 24.7 & 78 & 129 & 26.4 & 79 \\
\hline October & 13 & 27.4 & 62 & 49 & 26.4 & 77 \\
\hline November & 21 & 28.7 & 54 & 20 & 27.2 & 73 \\
\hline December & 43 & 28.2 & 56 & 9 & 27.4 & 73 \\
\hline Total/mean & 800 & 25.1 & 68 & 844 & 26.6 & 76 \\
\hline
\end{tabular}

Source: Values were obtained using equipment installed at Sítio Macaquinhos, Remígio, PB

Table 2. Physical and chemical characterization of soil and bovine manure before installation of experiment

\begin{tabular}{|c|c|c|c|c|}
\hline Physical attributes & Value & Chemical attributes & Soil & $\begin{array}{l}\text { Bovine } \\
\text { manure }\end{array}$ \\
\hline $\mathrm{SD}\left(\mathrm{kg} \mathrm{dm}^{-3}\right)$ & 1.60 & $\mathrm{pH}$ & 6.10 & 8.64 \\
\hline $\mathrm{PD}\left(\mathrm{kg} \mathrm{dm}^{-3}\right)$ & 2.66 & $P\left(\mathrm{mg} \mathrm{dm}^{-3}\right)$ & 17.78 & 36.11 \\
\hline TP (\%) & 0.39 & $\mathrm{~K}\left(\mathrm{mg} \mathrm{dm^{-3 } )}\right.$ & 78.69 & $7,892.3$ \\
\hline Sand $\left(\mathrm{g} \mathrm{kg}^{-1}\right)$ & 834 & $\mathrm{Na}^{+}\left(\mathrm{cmol}_{\mathrm{c}} \mathrm{dm}^{-3}\right)$ & 0.07 & 3.86 \\
\hline Silt $\left(\mathrm{g} \mathrm{kg}^{-1}\right)$ & 113 & $\mathrm{H}^{+}+\mathrm{Al}^{3+}\left(\mathrm{cmol}_{\mathrm{c}} \mathrm{dm}^{-3}\right)$ & 1.40 & 1.24 \\
\hline Clay $\left(\mathrm{g} \mathrm{kg}^{-1}\right)$ & 53 & $\mathrm{Al}^{3+}\left(\mathrm{cmol}_{\mathrm{c}} \mathrm{dm}^{-3}\right)$ & 0 & 0.0 \\
\hline Ada $\left(\mathrm{g} \mathrm{kg}^{-1}\right)$ & 13 & $\mathrm{Ca}^{2+}\left(\mathrm{cmol}_{\mathrm{c}} \mathrm{dm}^{-3}\right)$ & 2.32 & 5.40 \\
\hline GF (\%) & 75.4 & $\mathrm{Mg}^{2+}\left(\mathrm{cmol}_{c} \mathrm{dm}^{-3}\right)$ & 0.47 & 4.5 \\
\hline DI (\%) & 24.6 & $\mathrm{SB}\left(\mathrm{cmol}_{\mathrm{c}} \mathrm{dm}^{-3}\right)$ & 3.07 & - \\
\hline $\operatorname{UCC}\left(\mathrm{g} \mathrm{kg}^{-1}\right)$ & 98.6 & CEC $\left(\mathrm{cmol}_{\mathrm{c}} \mathrm{dm}^{-3}\right)$ & 4.47 & - \\
\hline $\operatorname{Upmp}\left(\mathrm{g} \mathrm{kg}^{-1}\right)$ & 44 & V (\%) & 68.59 & - \\
\hline AW $\left(\mathrm{g} \mathrm{kg}^{-1}\right)$ & 54.6 & OM $\left(\mathrm{g} \mathrm{kg}^{-1}\right)$ & 5.27 & 591.68 \\
\hline Textural Classification & Sand & & & \\
\hline
\end{tabular}

SD - Soil density; PD - Particle density; TP - Total porosity; Ada - Clay dispersed in water; GF - Degree of flocculation; DI - Dispersion index of clay (100 - GF); Ucc - Soil water content at field capacity; Upmp - Soil water content at the permanent witing point; AW - Available water; $\mathrm{SB}$ - Sum of exchangeable bases $\left(\mathrm{Ca}^{2+}+\mathrm{Mg}^{2+}+\mathrm{K}^{+}+\mathrm{Na}^{+}\right)$; $\mathrm{CEC}$ - Cation exchange capacity $\left[\mathrm{SB}+\left(\mathrm{H}^{+}+\mathrm{Al}^{3+}\right) ; \mathrm{V}\right.$ - Saturation by exchangeable bases (SB/CEC)100; OM - Organic matter in the soil and bovine manure

matter in the form of bovine manure before the experiment, which contributed to the change from dystrophic to eutrophic conditions. Bovine manure diluted in water, at a ratio of $1: 1$ (50\%), was characterized regarding salinity (Richards, 1954) for irrigation water (Table 3 ).

Treatments were designed in randomized blocks with three replicates and 12 plants per plot, using a $2 \times 2 \times 2$ factorial scheme, with reference to: irrigation water electrical conductivity values of 0.35 and $4.00 \mathrm{dS} \mathrm{m}^{-1}$; soil without and with bovine biofertilizer at 0 and $50 \%$ of the recommended dose of $15 \mathrm{~L} \mathrm{~m}^{2}$, respectively (Dias et al., 2013); and fertilization using two sources of potassium $\left(60 \% \mathrm{~K}_{2} \mathrm{O}\right)$, these being conventional and slow-release potassium chloride (polymercoated). This latter input does not differ from conventional $\mathrm{KCl}$ in terms of elementary composition; however, the coating allows a gradual liberation of potassium over time, keeping it available to plants for a longer period. Pits $(40 \times 40 \times 40 \mathrm{~cm})$ were opened, and prepared using soil from the top $20 \mathrm{~cm}$ layer.

Due to the calcium and magnesium values (Table 2), a $100 \mathrm{~g}$ mixture was blended with the superficial layer material. This 
Table 3. Chemical characterization with regard to salinity of bovine biofertilizer diluted in water at a ratio of 1:1 (50\%)

\begin{tabular}{|c|c|c|c|c|c|c|c|c|c|c|c|}
\hline Attributes & pH & $\begin{array}{c}E C \\
d S m^{-1}\end{array}$ & $\mathrm{Ca}^{2+}$ & $\mathrm{Mg}^{2+}$ & $\mathrm{Na}^{+}$ & $\mathrm{K}^{+}$ & $\mathrm{Cl}^{-}$ & $\mathrm{CO}_{3}{ }^{2-}$ & $\mathrm{HCO}_{3}$ & $\mathrm{SO}_{4}^{2-}$ & \multirow[t]{2}{*}{$\begin{array}{c}\text { SAR } \\
{\left[\mathrm{mmol} \mathrm{L}^{-1}\right]^{1 / 2}}\end{array}$} \\
\hline Biofertilizer & 6.37 & $\begin{array}{c}\mathrm{dS} \mathrm{m}^{-1} \\
3.10\end{array}$ & \multicolumn{7}{|c|}{$\mathrm{mmol}_{\mathrm{G}} \mathrm{L}^{-1}$} & 3.53 & \\
\hline
\end{tabular}

EC - Electrical conductivity; SAR - Sodium adsorption rate; $\mathrm{C}_{4}$ - High risk of increased salinity in soil; $\mathrm{S}_{1}$ - Low risk of increasing soil sodium concentrations by irrigation

mixture comprised $75 \%$ dolomitic limestone $(48 \% \mathrm{CaO}, 4.5 \%$ $\mathrm{MgO}$, and $78 \%$ relative power of total neutralization (PRNT)), and $25 \%$ agricultural gypsum $\left(\mathrm{CaSO}_{4} \cdot 2 \mathrm{H}_{2} \mathrm{O}\right)$, with $24 \% \mathrm{CaO}$, $16 \% \mathrm{~S}, 0.81 \% \mathrm{P}_{2} \mathrm{O}_{5}$, and $14 \%$ moisture, together with $10 \mathrm{~L}$ bovine manure with a $\mathrm{C} / \mathrm{N}$ ratio of $18: 1$, discounting the $5 \%$ humidity.

Seedlings were grown from seeds of the passion fruit cultivar BRS Gigante Amarelo. Nitrogen fertilizer incorporating urea and potassium (conventional and slow-release $\mathrm{KCl}$ )) was applied monthly to the soil surface, while phosphorus fertilizer (as simple superphosphate) was applied every two months. During the experimental period, $596 \mathrm{~kg} \mathrm{ha}^{-1}$ of urea, $313 \mathrm{~kg} \mathrm{ha}^{-1}$ of single superphosphate, and $446 \mathrm{~kg} \mathrm{ha}^{-1}$ of potassium chloride were applied. The plants were supported by espalier with flat wire $\mathrm{n}^{\circ} 12$, installed at the height of $2.2 \mathrm{~m}$. Crop treatments and phytosanitary management were carried out whenever considered necessary on the basis of visual monitoring.

Irrigation water of salinity of 0.35 and $4.00 \mathrm{dS} \mathrm{m}^{-1}$ was obtained from a superficial dam and by adding non-iodized sodium chloride ( $92 \%$ purity) in dam water, respectively. The biofertilizer was produced by anaerobic fermentation of fresh bovine manure and water (Dias et al., 2013), applied at the rate of $6 \mathrm{~L} \mathrm{~m}^{-2}$ (corresponding to $50 \%$ of the recommended value, after dilution with dam water). It was then applied at a fertilizer:water ratio of 1:1, one day and every 90 days after seedling transplantation (DAT), over an area of $0.8 \mathrm{~m}^{2}$ (50 $\mathrm{cm}$ of radius, with the plant being located in the middle of the pit). In each biofertilizer application, plants excluded from fertilizer input were irrigated using the same volume of each water type.

Plants were irrigated every $48 \mathrm{~h}$, based on the maximum daily water depth of potential evapotranspiration - ET (14 $\mathrm{L} \mathrm{plant}^{-1} \mathrm{~d}^{-1}$ ), obtained by the product of evaporation from Class "A" tank - ET, installed at the experimental location (ET $\left.=\mathrm{ET}_{\mathrm{a}} \times 0.75\right)$, and by crop coefficient $\left(\mathrm{K}_{\mathrm{c}}\right)$ of $0.2,0.4,0.8$, and $1.2\left(\mathrm{ET}_{\mathrm{c}}=\mathrm{ET}_{\mathrm{o}} \times \mathrm{K}_{\mathrm{c}}\right)$, where $\mathrm{ET}_{\mathrm{c}}$ is the crop evapotranspiration) with reference to the first $60 \mathrm{DAT}$, from 60 to $90 \mathrm{DAT}, 90$ to 115 DAT, and from flowering to harvest (Souza et al., 2016). For treatments irrigated with water of salinity $4.00 \mathrm{dS} \mathrm{m}^{-1}$, the irrigation depth was $10 \%$ superior to the irrigation depth of the lower salinity treatment, in order to reduce risks of salinity by lixiviation of salts present in the root environment (Ayers \& Westcot, 1999).

Leaf samples were collected at the beginning of flowering (Malavolta et al., 1997) in order to evaluate the macronutrient nutritional status of plants $\left(\mathrm{N}, \mathrm{P}, \mathrm{K}^{+}, \mathrm{Ca}^{2+}, \mathrm{Mg}^{2+}\right.$, and $\left.\mathrm{S}\right)$, as well as the sodium on the foliar tissue dry matter, using the methodologies suggested by EMBRAPA (2009). Nitrogen was extracted by sulfuric acid (total Kjeldahl N). Nitricperchloric extract was used for the other elements: phosphorus (colorimetry), potassium and sodium (flame photometry), calcium and magnesium (atomic absorption), and sulfur (turbidimetry). Fruits were conditioned in plastic boxes, in order to quantify their average mass. Results were submitted to a variance analysis using $\mathrm{F}$ test, with the means compared with Tukey test at 5\% probability, using the Statistical Analysis System software program (SAS, 2011).

\section{Results AND Discussion}

Irrigation with non-saline water, in comparison to initial situation of the soil (Table 2), increased the condition from non-saline $\left(\mathrm{EC}_{\mathrm{se}}<2 \mathrm{dS} \mathrm{\textrm {m } ^ { - 1 }}\right.$, where $\mathrm{EC}_{\mathrm{se}}$ is the electrical conductivity of the soil saturation extract) to slightly saline $\left(2<\mathrm{EC}_{\mathrm{se}}<4 \mathrm{dS} \mathrm{m}^{-1}\right)$. Irrigation with saline water increased the electrical conductivity of the soil saturation extract, independently of the treatments with biofertilizer or potassium sources (Figure 1). Increases in soil salinity were mostly due to irrigation with the different water treatments for 115 days DAT, but were also responses to the elevated saline index of $116 \%$ of $\mathrm{KCl}$, and the high electrical conductivity of the biofertilizer $\left(3.1 \mathrm{dS} \mathrm{m}^{-1}\right)$ that was applied one day before and at 90 DAT.

In the soil irrigated with non-saline water and fertilized with slow-release $\mathrm{KCl}$, the electrical conductivity of the soil extract was $14.05 \%$ lower than in the treatments fertilized with conventional $\mathrm{KCl}$. In the treatments irrigated with saline

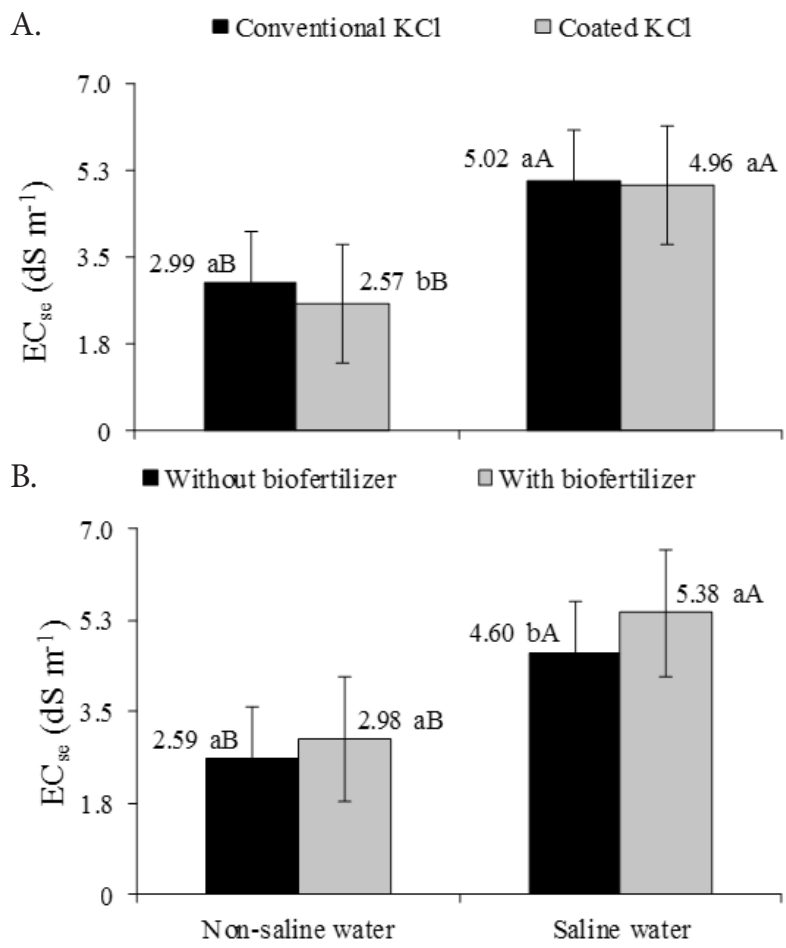

The same lowercase letters on columns denoting the same water treatment (saline or nonsaline), and the same uppercase letters on columns for different water treatments, indicate there was no statistical difference from each other according to a Tukey test $(p \leq 0.05)$

Figure 1. Electrical conductivity of the soil saturation extract $\left(\mathrm{EC}_{\mathrm{se}}\right)$ in the $0-40 \mathrm{~cm}$ layer at the beginning of flowering in yellow passion fruit plants, at 115 days after transplantation, in relation to water salinity, soil treated with conventional and organic polymer-coated $\mathrm{KCl}(\mathrm{A})$, and without and with biofertilizer (B) 
water, there was no statistical difference between the electrical conductivity values of the soil saturation extract treated with conventional or slow-release potassium chloride (Figure 1A). The salinity of soil irrigated with non-saline water did not differ among the bovine biofertilizer treatments, but saline water and biofertilizer elevated soil salinity by $16.9 \%$ compared with treatments without natural input (Figure 1B).

Electrical conductivity levels in the soil saturation extract above $4.0 \mathrm{dS} \mathrm{m}^{-1}$ (Figure 1) compromised growth, promoted nutritional imbalance, and impaired the productive capacity of most crops (Richards, 1954), with negative impacts on growth and plant production. Rameshwaran et al. (2016) made similar observations for red pepper (Capsicum annuum L.), as did Vieira et al. (2016) for cherry tomato (Lycopersicon esculentum Mill), and Nascimento et al. (2016) for yellow passion fruit. This negative effect is even more pronounced in plants that are sensitive or moderately sensitive to salinity, such as the yellow passion fruit.

Analysis of the $\mathrm{N}$ levels in leaf dry matter of yellow passion fruit (44.76 and $46.36 \mathrm{~g} \mathrm{~kg}^{-1}$ for non-saline and saline water treatments, respectively; Figure 2A) confirmed that plants irrigated with water of high electrical conductivity $\left(4.0 \mathrm{dS} \mathrm{m}^{-1}\right)$ presented on an average $\mathrm{N}$ content that was $3.5 \%$ higher than in plants irrigated with low conductivity water $\left(0.35 \mathrm{dS} \mathrm{m}^{-1}\right)$. According to Malavolta et al. (1997), an N amount of between 40 and $50 \mathrm{~g} \mathrm{~kg}^{-1}$ is sufficient, indicating that, regardless of the electrical conductivity of the irrigation water, plants were
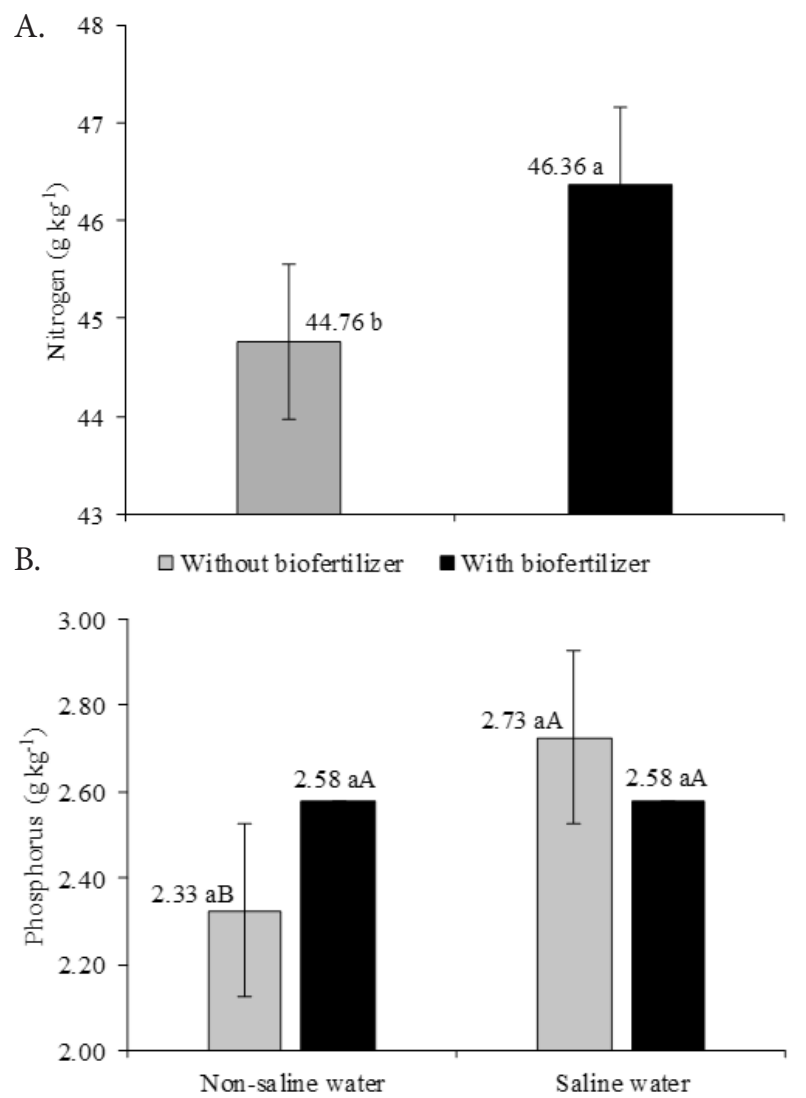

Columns labeled with the same lowercase letters indicate no difference in phosphorus content, and columns with the same uppercase letter also indicate no difference, in each case in the absence or presence of biofertilizer and under the same type of water treatment (saline or non-saline)

Figure 2. Nitrogen (A) and phosphorus (B) content in the leaf dry matter of yellow passion fruit, in relation to irrigation with non-saline and saline water, on soil with and without biofertilizer adequately supplied with nitrogen. It is possible that the monthly application of nitrogen fertilization with urea and its incorporation to a depth of $5 \mathrm{~cm}$, in order to avoid ammonia volatilization, enabled more availability of this macronutrient to plants during the phenological stage. In addition, salinity possibly influenced leaf dry matter production, thus concentrating the nitrogen content.

Phosphorus levels in the leaf dry matter of plants irrigated with water of low and high salinity did not differ between treatments with and without biofertilizer (Figure 2B). However, $P$ leaf content of plants under electrical conductivities, in the absence of any organic input, was observed to be higher (by $17.2 \%$, at $2.73 \mathrm{~g} \mathrm{~kg}^{-1}$ ) in plants irrigated with saline water, compared with plants irrigated with non-saline water (2.33 $\left.\mathrm{g} \mathrm{kg}^{-1}\right)$. Bosco et al. (2009) have observed the same trend in eggplant (Solanum melongena). However, Cruz et al. (2006) report a higher $\mathrm{P}$ leaf content in plants irrigated without than with saline stress for yellow passion fruit cultivated in a nutrient solution. According to Malavolta et al. (1997), the phosphorus values obtained in this study are below the amplitude of between 4.0 and $5.0 \mathrm{~g} \mathrm{~kg}^{-1}$ considered adequate for crops.

The potassium content in plant leaves irrigated with nonsaline water and fertilized with coated $\mathrm{KCl}$ was higher (by $6.5 \% ; 37.45 \mathrm{~g} \mathrm{~kg}^{-1}$ ) than the average level in plants irrigated with saline water. An inverse trend was observed for soil fertilized with conventional $\mathrm{KCl}$, where the average leaf $\mathrm{K}$ content was $9.8 \%$ (38.93 $\left.\mathrm{g} \mathrm{kg}^{-1}\right)$ higher in plants irrigated with saline than in non-saline water $\left(35.45 \mathrm{~g} \mathrm{~kg}^{-1}\right)$ (Figure 3A). The reduction in $\mathrm{K}$ leaf content in plants irrigated with saline water and fertilized with coated $\mathrm{KCl}$ may have occurred because of competition between $\mathrm{Na}^{+}$and $\mathrm{K}^{+}$on the absorptive sites of the cell membranes (Cruz et al., 2006). For plants fertilized with conventional $\mathrm{KCl}$, the continuous availability of $\mathrm{K}^{+}$in the soil, due to the monthly fertilization regime, may have contributed to an ion predominance in relation to $\mathrm{Na}^{+}$on the exchange site of soil irrigated with saline water, a factor that would have promoted the availability, absorption, and accumulation of this essential nutrient in the foliar tissue of plants (Nascimento et al., 2011). Despite this variation, as highlighted by Malavolta et al. (1997), leaf potassium content was within the range of 35 and $45 \mathrm{~g} \mathrm{~kg}^{-1}$ considered adequate for the crop.

Sulfur content in plants treated with biofertilizer reduced from 2.89 to $2.71 \mathrm{~g} \mathrm{~kg}^{-1}$ (Figure $3 \mathrm{~B}$ ). These values are below the optimum range ( 4.0 to $4.6 \mathrm{~g} \mathrm{~kg}^{-1}$ ) determined by Cruz et al. (2006) for yellow passion fruit grown in nutrient solution of high electrical conductivity, and are also below the range considered adequate for this crop, which is between 3.0 and $4.0 \mathrm{~g} \mathrm{~kg}^{-1}$ (Malavolta et al., 1997). Although the soil was fertilized bimonthly with single superphosphate ( $8 \% \mathrm{~S})$, the decreased levels of this macronutrient observed in plants which received biofertilizer may have occurred due to microbial populations in the organic input (Marrocos et al., 2012), which influence sulfur transformations in the soil. Another possibility is that, although organic matter is the main source of sulfur in the soil, diluting the biofertilizer at a proportion of $50 \%$ could have significantly reduced the nutrient availability to plants.

Applying slow-release $\mathrm{KCl}$ fertilizer increased the sodium content from 2.52 to $2.89 \mathrm{~g} \mathrm{~kg}^{-1}$, which was $14.6 \%$ higher than for plants in soil treated with conventional potassium chloride (Figure 3C). The higher sodium accumulation in the leaves of passion fruit grown under the slow-release $\mathrm{KCl}$ application was probably due to the lower potassium content 
A.

$\square$ Conventional $\mathrm{KCl} \quad \mathbf{\square}$ Coated $\mathrm{KCl}$
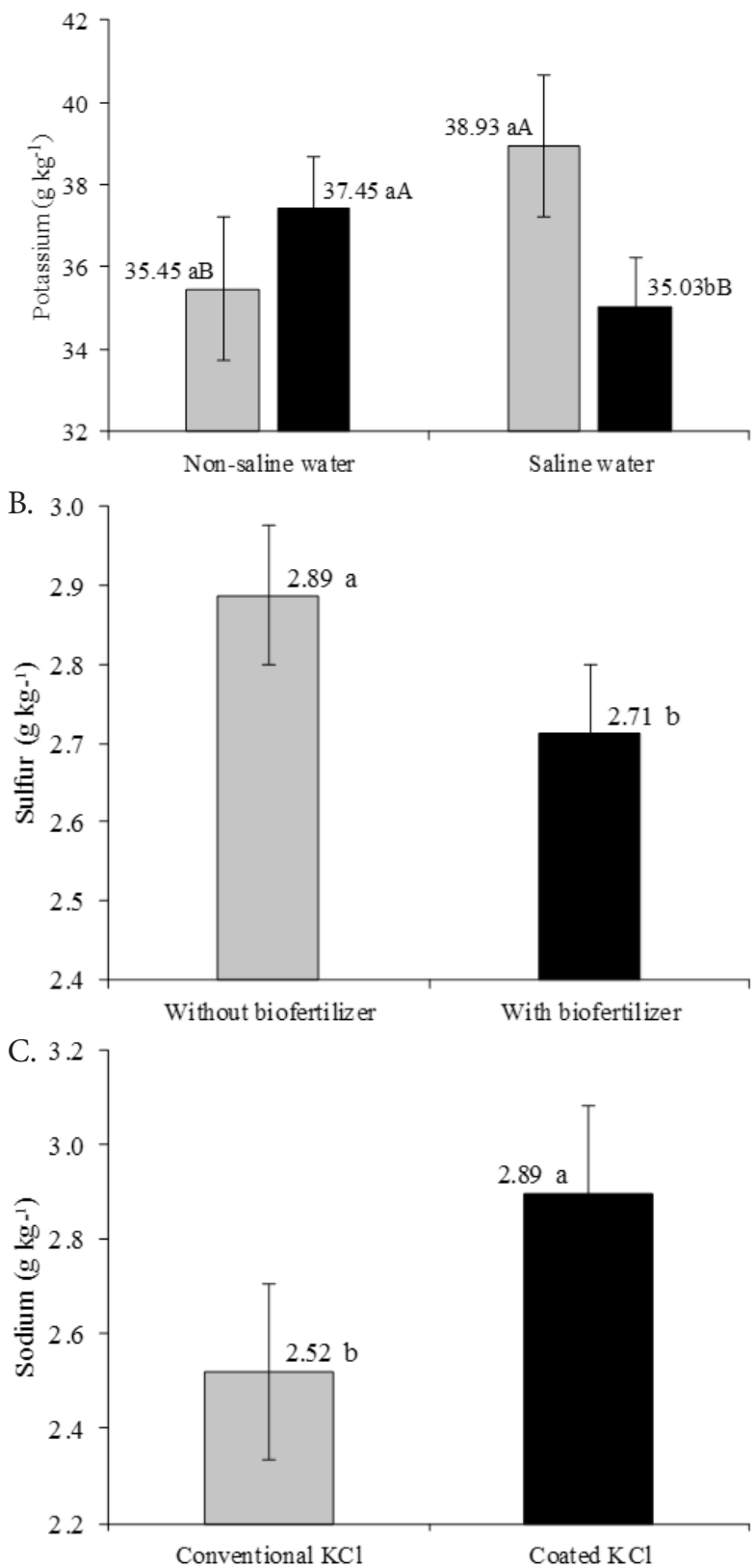

The same lower case letters for columns representing potassium leaf content denote there was no difference according to potassium type, under the same water treatment (saline or non-saline); the same upper case letters on columns denote no difference according to type of water for the same potassium type. This was in each case according to a Tukey test $(p \leq 0.01)$ Figure 3. Potassium, sulfur, and sodium levels in the leaf dry matter of yellow passion fruit plants, as a function of the interaction between potassium type (conventional or polymer-coated) and water irrigation treatment (non-saline and saline water - A), on soil without and with bovine biofertilizer application (B), and potassium type (C)

in the soil compared with the conventional $\mathrm{KCl}$ application, especially when saline water irrigation was used, resulting in a correspondingly lower accumulation of potassium in the leaves of yellow passion fruit (Figure 3A). According to Dias et al. (2016), a sodium leaf content above $2.5 \mathrm{~g} \mathrm{~kg}^{-1}$ may cause toxicity and compromise photosynthetic activity in plants.

The average fruit mass decreased with increasing electrical conductivity of the irrigation water (Figure 4). The average values for non-saline and saline water were 221.26 and $200.92 \mathrm{~g}_{\text {fruit }}{ }^{-1}$, respectively, representing a $9.2 \%$ reduction in plants irrigated with saline water $\left(4.0 \mathrm{dS} \mathrm{m}^{-1}\right)$. Despite this reduction, it was confirmed that both treatments yielded fruit mass values above those of 191.29 and $141.46 \mathrm{~g}_{\text {fruit }}{ }^{-1}$ determined by Dias et al. (2012) in soil irrigated with non-saline $\left(0.5 \mathrm{dS} \mathrm{m}^{-1}\right)$ and saline water $\left(4.5 \mathrm{dS} \mathrm{m}^{-1}\right)$, respectively. Pereira et al. (2017), studying the influence of saline water irrigation on the production components of five melon (Cucumis melo L.) cultivars, have determined that an increase in electrical conductivity of irrigation water from 0.54 to $3.90 \mathrm{dS} \mathrm{m}^{-1}$ reduced the number of fruits per plant and the fruit yield.

This probably occurred due to the large osmotic adjustment of the plants resulting from the soil physical characteristics, as the monthly $\mathrm{KCl}$ fertilization increased the ratio $\mathrm{K}^{+} / \mathrm{Na}^{+}$, and because of the benefits of biofertilizer-derived humic substances. Osmotic adjustment enables water absorption in elevated salinity conditions, thus contributing to plant growth and production, even at modest levels.

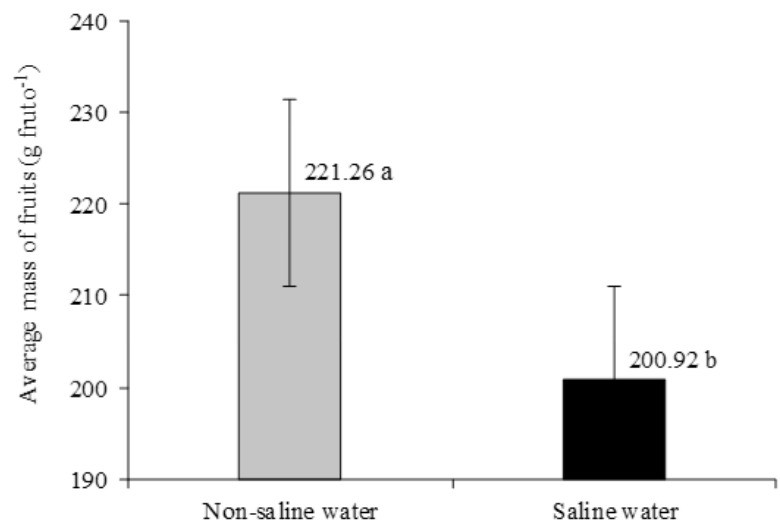

Figure 4. Average fruit mass of yellow passion fruit in plants irrigated with non-saline and saline water

\section{Conclusions}

1. The combination of saline water with bovine biofertilizer application raises soil salinity to a similar proportion to that obtained by application of saline water and potassium chloride either conventional or protected potassium chloride by an organic polymer coating.

2. Increases in saline concentrations associated with both types of potassium chloride and bovine biofertilizer elevated the soil salinity from non-saline to saline level.

3. Plants of passion fruit cv. BRS Gigante Amarelo were deficient in phosphorus, calcium, magnesium, and sulfur, but produced fruits of an adequate mass for the consumer market.

\section{Literature Cited}

Alvares, C. A.; Stape, J. L.; Sentelhas, P. C.; Gonçalves, J. L. de M.; Sparovek, G. Koppen's climate classification map for Brazil. Meteorologische Zeitschrift, v.22, p.711-728, 2014. https://doi. org/10.1127/0941-2948/2013/0507

Ayers, R. S.; Westcot, D. W. A qualidade da água na agricultura. 2.ed. Campina Grande: UFPB, 1999. 153p.

Bernardes, T. G.; Silveira, P. M. da; Carvalho, M. T. de M.; Madari, B. E.; Carvalho, M. da C. S. Produtividade do feijoeiro irrigado em razão de fontes de adubo nitrogenado estabilizado e de liberação controlada. Revista Ceres, v.62, p.614-620, 2015. https://doi. org/10.1590/0034-737X201562060015 
Borges, F. R. M.; Viana, T. V. de A.; Marinho, A. B.; Pinheiro Neto, L. G.; Azevedo, B. M. de. Gas exchange and leaf contents in bell pepper under energized water and biofertilizer doses. Revista Brasileira de Engenharia Agrícola e Ambiental, v.20, p.533-538, 2016. https://doi.org/10.1590/1807-1929/agriambi. v20n6p533-538

Bosco, M. R. de O.; Oliveira, A. B. de; Hernandez, F. F. F.; Lacerda, C. F. de. Influência do estresse salino na composição mineral da berinjela. Revista Ciência Agronômica, v.40, p.157-164, 2009.

Chilundo, M.; Joel, A.; Wesström, I.; Brito, R.; Messing, I. Effects of reduced irrigation dose and slow release fertilizer on nitrogen use efficiency and crop yield in a semi-arid loamy sand. Agricultural Water Management, v.168, p.68-77, 2016. https:// doi.org/10.1016/j.agwat.2016.02.004

Cruz, J. L.; Pelacani, C. R.; Ferreira, C. E.; Caldas, R. C.; Almeida, A. Q. de; Queiroz, J. R. de. Influência da salinidade sobre o crescimento, absorção e distribuição de sódio, cloro e macronutrientes em plântulas de maracujazeiro-amarelo. Bragantia, v.65, p.275-284, 2006. https://doi.org/10.1590/S0006-87052006000200009

Dias, N. da S.; Blanco, F. F.; Souza, E. R. de; Ferreira, J. F. da S.; Souza Neto, O. N. de; Queiroz, I. S. R. de. Efeitos dos sais na planta e tolerância das culturas à salinidade. In: Gheyi, H. R.; Dias, N. da S.; Lacerda, C. F. de; Gomes, E. N. Manejo da salinidade na agricultura: Estudos básicos e aplicados. 2.ed. Fortaleza: INCTSal, 2016. Cap.11, p.151-162.

Dias, T. J.; Cavalcante, L. F.; Nunes, J. C.; Freire, J. L. de O.; Nascimento, J. A. M. Qualidade física e produção do maracujá amarelo em solo com biofertilizante irrigado com águas salinas. Semina: Ciências Agrárias, v.33, p.2905-2918, 2012. https://doi.org/10.5433/16790359.2012v33Supl1p2905

Dias, T. J.; Cavalcante L. F.; Pereira, W. E.; Freire, J. L. de O.; Souto, A. G. de L. Irrigação com água salina em solo com biofertilizante bovino no crescimento do maracujazeiro amarelo. Semina: Ciências Agrárias, v.34, p.1639-1652, 2013. https://doi. org/10.5433/1679-0359.2013v34n4p1639

Donagema, G. K.; Campos, V. D. B. de; Calderano, S. B.; Teixeira, W. G.; Viana, J. H. M. Manual de métodos de análise de solo. 2.ed. Rio de Janeiro: Embrapa Solos, 2011. 230p.

EMBRAPA - Empresa Brasileira de Pesquisa Agropecuária. Manual de análises químicas de solos, plantas e fertilizantes. 2.ed. Rio de Janeiro: Embrapa Solos, 2009. 627p.

EMBRAPA - Empresa Brasileira de Pesquisa Agropecuária. Sistema brasileiro de classificação de solos. 3.ed. Rio de Janeiro: Embrapa Solos, 2013. 353p.

Glaeser, L. C.; Vitt, D. H.; Ebbs, S. Responses of the wetland grass, Beckmannia syzigachne, to salinity and soil wetness: Consequences for wetland reclamation in the oil sands area of Alberta, Canada. Ecological Engineering, v.86, p.24-30, 2016. https://doi. org/10.1016/j.ecoleng.2015.10.009
Lima, B. L. de C.; Lacerda, C. F. de; Ferreira Neto, M.; Ferreira, J. F. da S.; Bezerra, A. M. E.; Marques, E. C. Physiological and ionic changes in dwarf coconut seedlings irrigated with saline water. Revista Brasileira de Engenharia Agrícola e Ambiental, v.21, p.121-127, 2017. https://doi.org/10.1590/1807-1929/agriambi.v21n2p122-127

Malavolta, E.; Vitti, G. C.; Oliveira, S. A. de. Avaliação do estado nutricional das plantas. Princípios e aplicações. 1.ed. Piracicaba: Potafos, 1997. 319p.

Marrocos, S. de T. P.; Novo Júnior, J.; Granjeiro, L. C.; Ambrósio, M. M. de Q.; Cunha, A. P. A. da. Composição química e microbiológica de biofertilizantes em diferentes tempos de decomposição. Revista Caatinga, v.25, p.34-43 2012.

Melo Júnior, J. C. F. de; Costa, D. dos S.; Gervásio, E. S.; Lima, A. M. N.; Sediyama, G. C. Efeito de níveis de depleção de água no substrato e doses de fertilizante de liberação controlada na produção de mudas de maracujazeiro amarelo. Irriga, v.20, p.204-219, 2015. https://doi.org/10.15809/irriga.2015v20n2p204

Nascimento, J. A. M. do; Cavalcante, L. F.; Cavalcante, I. H. L.; Pereira, W. E.; Dantas, S. A. G.; Medeiros, S. A. da S. The impacts of biofertilizer and mineral fertilization on the growth and production of yellow passion fruit irrigated with moderately saline water. Ciencia e Investigación Agraria, v.43, p.253-262, 2016. https://doi.org/10.4067/S0718-16202016000200008

Nascimento, J. A. M. do; Cavalcante, L. F.; Dantas, S. A. G.; Silva, S. A. da. Estado nutricional de maracujazeiro-amarelo irrigado com água salina e adubação organomineral. Revista Brasileira de Fruticultura, v.especial, p.729-735, 2011.

Pereira, F. A. de L.; Medeiros, J. F. de; Gheyi, H. R.; Dias, N. da S.; Preston, W.; Vasconcelos, C. B. e L. Tolerance of melon cultivars to irrigation water salinity. Revista Brasileira de Engenharia Agrícola e Ambiental, v.21, p.846-851, 2017. https://doi.org/10.1590/18071929/agriambi.v21n12p846-851

Rameshwaran, P.; Tepe, A.; Yazar, A.; Ragab, R. Effects of dripirrigation regimes with saline water on pepper productivity and soil salinity under greenhouse conditions. Scientia Horticulturae, v.199, p.114-123, 2016. https://doi.org/10.1016/j. scienta.2015.12.007

Richards, L. A. Diagnosis and improvement of saline and alkaline soils. Washington: United States Salinity Laboratory Staff, 1954. 160p.

SAS - Statistical Analysis System. I - SAS/STAT 9.3 User’s Guide. Cary: SAS Institute Inc., 2011. 8621p.

Souza, J. T. A. de; Cavalcante, L. F.; Nunes, J. C.; Bezerra, F. T. C.; Nunes, J. A. da S.; Silva, A. R.; Oresca, D.; Cavalcante, A. G. Effect of saline water, bovine biofertilizer and potassium on yellow passion fruit growth after planting and on soil salinity. African Journal of Agricultural Research, v.11, p.2994-3003, 2016. https:// doi.org/10.5897/AJAR2016.11233

Vieira, I. G. S.; Nobre, R. G.; Dias, A. S.; Pinheiro, F. W. A. Cultivation of cherry tomato under irrigation with saline water and nitrogen fertilization. Revista Brasileira de Engenharia Agrícola e Ambiental, v.20, p.55-61, 2016. https://doi.org/10.1590/18071929/agriambi.v20n1p55-61 